of some amniotes is characterized during its development by the possession of a glomerular border which projects in the splanchnocœle and is separated from it by peritoneal epithelium. The method of development and the functions of the glomerular border are unknown; the suggestion is made that it may be concerned with secretion of cœlomic fluid.

;Fraser, E. A., Biol. Rev., 25, 159 (1950).

"Felix, $W$., in Keibel and Mall, "Manual of Human Ernbryology", 2 (1912).

- Felix W., in Hertwig's “Handbuch verg. Exp. Entwick. d. Wirbeltiere", 8, T.1, 81 (1906)

'Tribe, M., and Fisk, A., Proc. Zool. Soc. Lond, B, 110, 153 (1941).

Davies, J., J. Anat., 84, 95 (1950).

-Wiedersheim, R., Atch. Mikr. Anat., 36, 410 (1890).

7 Walsche, L. de, Arch. Biol., 39, 1 (1929).

- Sedgwick, A., Quart. J. Micr. Sci, 20, 146 (1880); 21, 432 (1881).

- Davies, J., and Davies, D. V., Proc. Zool. Soc. Lond., 120, 73 (1950).

\section{CENTRAL FOOD TECHNOLOGICAL RESEARCH INSTITUTE, MYSORE}

A

MYSORE palace has been converted into a temple of science, to house one of the eleven national laboratories planned by the Council of Scientific and Industrial Research of India. The research centre, thus magnificently housed, concerns itself with food technology. The Industrial Research Planning Committee appointed by the Council some years ago recommended the creation of such a research centre, and early in 1948 steps were taken to set up a Central Food Technological Research Institute. The Mysore Government, headed by the Hon. Mr. K. C. Reddy, came forward at this stage with the offer of the magnificent Cheluvamba mansion with the attached buildings, parks, grounds, etc., covering in all 150 acres of land. This mansion, which was the residence of the late Princess Cheluvajammanni Avaru, the Maharaja's aunt, is a solid and imposing palatial structure beautifully maintained. Mysore, besides, had additional attractions : it has an equable climate, it is situated in close proximity to areas using rice, millet and tubers respectively as major articles of diet, it is the centre of a region growing a large variety of fruit and vegetables, and it has special facilities with regard to water supply and electricity. The other well-known centres of scientific research in this area are the Indian Institute of Science and Sir C. V. Raman's Institute, both at Bangalore. The Nutrition Research Institute at Coonoor is not far away.

The offer was accepted and the gift formally received by Mr. Jawaharlal Nehru, as president of the Council of Scientific and Industrial Research, in December 1948. Dr. V. Subrahmanyan, as assistant director of planning, took in hand the difficult job of converting the mansion into a research institute without permitting the alterations and scientific fittings to destroy the character of the building. By the end of July 1949, the first of the laboratories, the library and the animal house were already functioning.

The main building together with the rear block covers about 110,000 sq. ft. Most of the laboratories, the offices and the library fill the front, while the workshop, machine rooms, stores, etc., are placed in the rear part. The former stables have been appropriately converted into the animal house, which forms a separate block covering about 7,000 sq. ft. Part of this block has been equipped for human metabolism experiments. Monkeys, rabbits and rats are the principal experimental animals used.

The Institute is to do pioneer work in food engineering in India. There is considerable scope for improving the yields from staple foods, thereby reducing the cost of processing, which includes milling, parboiling, making millet rice, manufacture of synthetic rice and of substitute foods from tapioca and other materials. The Institute will investigate problems connected with storage, refrigeration, dehydration, canning and fruit and vegetable preservation, with improving the palatability and digestibility of coarse foods, with the exploration of unfamiliar sources for nutriment, with food sanitation and the detection of adulterants, with the preparing of concentrated foods (including vitamins) - with all problems connected with food industries up to the pilot-plant stage.

Industries connected with food are of vital interest to India. Mr. Nehru, in his message at the inaugural function at Mysore on October 21, reminded people that his Government had laid down a target for food self-sufficiency during the 1951-52 season. Sir Shanti Swarup Bhatnagar, director of scientific and industrial research, pointed out that India's factory production in food industries (flour and rice milling, biscuit making, fruit and vegetable processing, vegetable oils, spirits, etc.) total Rs. 130 crores. Transactions in food imports and exports and in the home market total Rs. 204 crores, and this gives some idea of the vast dimensions of the sector which might be affected by work on food technology. India has a serious problem on hand in the form of its food deficit, but it should be possible to tackle a deficit of 10 per cent by preventing losses during storage caused by fungus, moisture, monkeys, rats and insects-and technological research already has shown the way to accomplish this. Sir Shanti Bhatnagar conveyed to the Hon. Mr. C. Rajagopalachari, who inaugurated the Institute, an assurance given by Dr. V. Subrahmanyan (now director of the Institute) that within a year the Mysore laboratories would be able to make a distinct contribution towards making up the national food deficit. Speaking of the work already being carried on in the Institute, Sir Shanti said that the Biochemistry and Processing Divisions have been concentrating on the production of suitably fortified grains prepared from different starch-bearing materials, pulses and seedcakes. They are also trying to utilize lucerne in human dietaries - in spite of its high food value, at present it is being used only for animal feeding. Work on the processing and preservation of jack fruit, citrus fruits and cashew fruit, and the standardization of predigested and concentrated protein foods is also making good progress. Sir Shanti directed attention also to work at the Forest Research Institute by Dr. S. Krishna, who has extracted a pectin-like product-a good substitute for starch-from tamarind seed, which at present is only waste material.

The possibilities of processed and synthetic foods were again referred to by Sir S. V. Ramamurthy, who spoke of "synthetic cereals" as "a second line of production": Dr. Subrahmanyan, who had already interested himself in making 'rice' from maize, at the suggestion of Sir S. V. Ramamurthy, turned at Mysore to tapioca and groundnut cake, both these ingredients being available in abundance. Work under Dr. V. Subrahmanyan has shown that 80 per 
cent tapioca and 20 per cent groundnut-cake powder is three times as nutritious as rice, and that 75 per cent rice and 25 per cent tapioca is as nutritious as whole rice. Dr. Subrahmanyan has also improved the manufacture of tapioca sago by the addition of 1 per cent of stearic acid, so that the grains no longer stick in cooking. His work has given results contrary to the common belief that tapioca debases rice. The practical value of such work can be immense. "Our production," said Sir S. V. Ramamurthy, "is 60 million tons and our deficit is 6 million tons. This deficit can be made up either from 20 million acres of cereals or only 2 million acres of synthetic cereals."

The inaugural function on Oetober 21 last, which was attended by many distinguished men of science and political leaders, was presided over by $\mathrm{His}$ Highness the Maharaja of Mysore. His Highness welcomed the Hon. C. Rajagopalachari and other distinguished guests, and in thanking Mr. Nehru for having accepted for the Institute his gift of the Cheluvamba mansion, His Highness paid a warm tribute to the Indian Government's zeal for progress in scientific research.

The Hon. Mr. C. Rajagopalachari in his address referred to the importance of problems of food technology and recalled how the Marhatta soldiers on their expeditions used to carry flattened rice and roasted pulses in their bags, showing that dehydration was nothing new. He referred also to the importance of subsidiary foods and directed attention to the need for investigations that would eliminate harmful constituents from otherwise edible material and thereby convert it into wholesome food. Mr. Rajagopalachari thanked His Highness and the Mysore Government for the gift of the mansion, as also did Sir Shanti Bhatnagar and Dr. Subrahmanyan.

Among other addresses on the occasion was one by the Deputy Minister for Food and Agriculture, and another by the Vice-Chancellor of the University of Mysore, who stressed the need for simplified cookery and expressed the hope that the Nutrition Research Institute at Coonoor would also gravitate to Mysore.

Sir C. V. Raman paid a tribute to Sir Shanti Bhatnagar's resourcefulness and organizing ability, and rejoiced that men of science are now being given a chance to do things. Speaking of the desperate food situation in India, he said : "We have a vast population in this country living on the land ... we must allow science to do something for feeding and nourishing this great population".

\section{SCIENTIFIC ADVISORY BOARD OF THE INDIAN RESEARCH FUND ASSOCIATION}

\section{ANNUAL REPORT FOR 1949}

$\mathrm{T}$ HE report for 1949 of the Scientific Advisory Board of the Indian Research Fund Association* includes some accounts of research carried out during the year, as well as giving the membership of the Board and its Advisory Committees, a list of papers published on medical research carried out under the auspices of the Indian Research Fund Association

* Report of the Scientiflc Advisory Board for the Year 1949. Pp xii +307. (New Delhi: Indian Research Fund Association, 1950.) 1 rupee. during 1949, and the programme of researches and miscellaneous grants recommended to the Governing Body for the year 1950-51.

Besides various inquiries on cholera carried out at the Central Research Institute, Kasauli, the King Institute, Guindy, Madras, and the School of Tropical Medicine, Calcutta, four inquiries on malaria are reported. The Malaria Institute of India, Delhi, was responsible for laboratory and field studies with insecticidal and mosquito-repellent formulations, including both 'Gammexane' and DDT, and at the School of Tropical Medicine, Calcutta, a comparative study was made of the action of paludrine, chloroquine and camoquin in equivalent doses with the view of devising a simple form of mass treatment for people in rural areas. At the Haffkine Institute, Bombay, about forty sulphone derivatives were synthesized, but negative results were obtained with the ten examined for prophylactic activity in the mosquito.

Nutrition researches included studies on pyridoxine and fatty-acid metabolism, on vitamin $D$, the influence of nutritional factors in liver disease and the influence of dietary protein on the nitrogen balance (at the Nutrition Research Laboratories, Coonoor); the biosynthesis of ascorbic acid, fattyacid oxidation by the guinea pig and the rat, and the absorption, excretion and effect of iron in foods (University College of Science and Technology, Calcutta); fat metabolism and experimental rickets (Seth G. S. Medical College, Bombay); nutritive value of soya-bean milk and curd (Indian Institute of Science, Bangalore); metabolism of vitamin A (AllIndia Institute of Hygiene and Public Health, Calcutta); and the biosynthesis of nicotinic acid by germinating pulses and by guinea pigs (Presidency College, Calcutta).

Leprosy inquiries at the School of Tropical Medicine, Calcutta, related to the intramuscular administration of sulphetrone, its concentration in the blood, excretion in urine and the relation between the blood and urinary concentrations and the use of $p$-aminosalicylic acid. The use of sulphetrone and other sulphones in leprosy was also studied at the Government Lady Willingdon Leprosy Sanatorium, Chingleput.

The curative value of aureomycin and chloromycetin in experimental plague infection in mice has been studied at the Haffkine Institute, Bombay, plague researches have included studies of the use of DD'T in plague control work in the Nilgiris district under the director of public health, Madras, which have shown that DDT is an extremely effective pulicide which should offer considerable savings on cyanogas, and a preliminary trial with 'Gammexane' has been made. Filariasis inquiries have included, besides screening tests on various compounds, the preparation of thirty new compounds at the B.J. Medical College, Poona, and the Technology Department of the Univer. sity of Bombay in the chemical part of a study aimed at changing the physical properties of drugs by the introduction of long alkyl chains which confer surface activity. In addition to $\mathrm{N}$-substituted derivatives of stibanilic acid and a range of $p$-alkoxyaniline antimonyl tartrates, derivatives of $p$-aminosalicylic acid have been included in the study.

The work on indigenous drugs at the School of Tropical Medicine, Calcutta, and at the Drug Research Laboratory, Jammu, continued, and at the University College of Science and Technology, Calcutta, an investigation of the action of snake venoms and their constituents on the biochemical activities of tissue 